\title{
Molecular markers in gliomas: impact for the clinician
}

\author{
Hofer, Silvia ; Lassman, Andrew B
}

\begin{abstract}
Over the last decade, understanding of glioma on a molecular level has greatly expanded. However, optimal incorporation of molecular markers into clinical care is controversial. We briefly review the potential utility of molecular stratification in refining histologic diagnosis, prognosis, and treatment decisions, focussing on 1p/19q co-deletion, MGMT promoter methylation, EGFR mutations, and IDH mutation. The most recently discovered IDH mutation is a striking example of a rapid implementation of a molecular marker for prognostication into common clinical use
\end{abstract}

DOI: https://doi.org/10.1007/s11523-010-0157-2

Posted at the Zurich Open Repository and Archive, University of Zurich ZORA URL: https://doi.org/10.5167/uzh-156217

Journal Article

Published Version

Originally published at:

Hofer, Silvia; Lassman, Andrew B (2010). Molecular markers in gliomas: impact for the clinician. Targeted oncology, 5(3):201-210.

DOI: https://doi.org/10.1007/s11523-010-0157-2 


\title{
Molecular markers in gliomas: impact for the clinician
}

\author{
Silvia Hofer • Andrew B. Lassman
}

Received: 26 May 2010 /Accepted: 7 August 2010 /Published online: 31 August 2010

(C) Springer-Verlag 2010

\begin{abstract}
Over the last decade, understanding of glioma on a molecular level has greatly expanded. However, optimal incorporation of molecular markers into clinical care is controversial. We briefly review the potential utility of molecular stratification in refining histologic diagnosis, prognosis, and treatment decisions, focussing on $1 \mathrm{p} / 19 \mathrm{q}$ codeletion, $M G M T$ promoter methylation, EGFR mutations, and $I D H$ mutation. The most recently discovered $I D H$ mutation is a striking example of a rapid implementation of a molecular marker for prognostication into common clinical use.
\end{abstract}

Keywords Glioma · MGMT · Molecular · 1p19q ·

Prognostic · Predictive $\cdot$ EGFR $\cdot$ IDH

\section{Introduction}

Adult patients with malignant gliomas almost always ultimately die from their disease. However, if the biology of gliomas is elucidated, targeted therapies may allow individualized patient care tailored to tumor biology. For example, the last several years have led to promising discoveries allowing molecular sub-classification of high-

S. Hofer $(\bowtie)$

Department of Oncology, University Hospital Zürich,

Zürich, Switzerland

e-mail: Silvia.Hofer@usz.ch

A. B. Lassman

Department of Neurology and Brain Tumor Center,

Memorial Sloan-Kettering Cancer Center,

New York, NY, USA

e-mail: lassmana@mskcc.org grade gliomas $[1,2]$ that can also supplement classic histology.

At this time, we rely primarily on clinical factors such as age, Karnofsky performance status, tumor size, presence of neurologic symptoms, and extent of resection to inform prognosis. These parameters and others have been used to identify prognostically important classes using recursive partitioning analysis (RPA) for patients with anaplastic astrocytomas and glioblastomas (GBMs) [3, 4]. They have been proven useful and were validated by subsequent glioma trials both at diagnosis and recurrence $[4,5]$. They are critical stratification factors for randomized phase III clinical trials and for interpretation of single arm phase II studies to ensure valid historic controls are used although selection bias cannot be completely eliminated, as would a control arm in a randomized trial. However, molecular stratification is also emerging as key to ensure trials with multiple arms are adequately balanced, and that results of single arm studies are not misinterpreted.

Currently there is no molecular marker in neurooncology to accurately predict drug responsiveness of tumors as stringently as the oncogene $B C R-A B L$ in chronic myelogenous leukemia. However, $M G M T$ promoter methylation predicts enhanced sensitivity to temozolomide chemotherapy, and some data suggest that response to epidermal growth factor receptor (EGFR) inhibitors depends on mutations in EGFR [6, 7]. Advances in understanding glioma biology may, therefore, assist in histologic classification, prognostication, and treatment decisions.

In relation to these clinical issues, this review will focus on $M G M T$ promoter methylation, $1 \mathrm{p} 19 \mathrm{q}$ co-deletion, isocitrate dehydrogenase (IDH) 1/2 mutation, and EGFR amplification/mutation (Table 1). 
Table 1 Frequency and possible role of tumor markers in glioma

\begin{tabular}{|c|c|c|c|c|c|}
\hline Molecular marker & $\begin{array}{l}\text { WHO II } \\
\text { low grade }\end{array}$ & $\begin{array}{l}\text { WHO III } \\
\text { anaplastic }\end{array}$ & $\begin{array}{l}\text { WHO IV } \\
\text { glioblastoma }\end{array}$ & Diagnostic role & Prognostic in \\
\hline $\begin{array}{l}M G M T \text { promoter } \\
\text { methylation }\end{array}$ & $\sim 93 \%$ [8] & $\sim 50-80 \%[13,14]$ & $\begin{array}{l}\sim 45 \%[9] \\
\sim 40 \% 1^{\circ} \mathrm{GBM} \\
\sim 70 \% 2^{\circ} \mathrm{GBM}\end{array}$ & & WHO II-IV $[9-15,18]$ \\
\hline $1 \mathrm{p} 19 \mathrm{q}$ co-deletion & $\sim 85 \%[30]$ & $\sim 65 \%[30]$ & $\sim 5-25 \%[42-45]$ & $\begin{array}{l}\text { WHO III oligodendroglial } \\
\text { subtype [33-39] }\end{array}$ & $\begin{array}{l}\text { WHO II-III } \\
{[14,40,46-48]} \\
\text { WHO IV unclear } \\
{[18,43,45,49]}\end{array}$ \\
\hline IDH $1 / 2$ mutation & $\sim 70-80 \%[64,65]$ & $\sim 65-70 \%$ [64-66] & $\begin{array}{l}<10 \% 1^{\circ} \mathrm{GBM}[64] \\
>80 \% 2^{\circ} \mathrm{GBM}[64]\end{array}$ & WHO I versus II [70] & WHO II-IV $[14,66,71]$ \\
\hline $\begin{array}{l}E G F R \text { amplification/ } \\
\text { mutation }\end{array}$ & & $\sim 10 \%[78]$ & $\sim 45 \%[2]$ & $\begin{array}{l}\text { WHO III astrocytic } \\
\text { subtype }[74,75] \\
\text { EGFR vIII } 1^{\circ} \text { GBM [73] }\end{array}$ & $\begin{array}{l}\text { WHO IV unclear } \\
{[18,76-78]}\end{array}$ \\
\hline
\end{tabular}

\section{$M G M T$ promoter methylation}

The importance of silencing DNA repair pathways, especially the DNA-repair enzyme AGT $\left(\mathrm{O}^{6}\right.$-alkylguanine DNA alkyltransferase) encoded by the gene $M G M T\left(\mathrm{O}^{6}\right.$-methylguanine-DNA-methyltransferase), has been the subject of substantial debate in recent years. A methylated (and thereby silenced) $M G M T$ promoter is observed in many cancers, including low-grade gliomas (up to $93 \%$ in one series) [8], and in $45 \%$ in a series of GBMs [9].

The landmark European Organisation for Research and Treatment (EORTC)-National Cancer Institute of Canada (NCIC) study demonstrated a survival advantage from the addition of the DNA methylating agent temozolomide to radiotherapy [10]. A companion molecular study of archival pre-treatment tissue [9], and 5-year follow up data [11] also demonstrated that patients with $M G M T$ methylated tumors derive the most benefit from temozolomide. For example, median survival was longer by 8.1 months in methylated cases (23.4 for radiotherapy and temozolomide versus 15.3 for radiotherapy alone); by contrast, there was less than 1-month difference in median survival in unmethylated cases (12.6 versus 11.8) [11]. However, it remains unclear whether a more favorable outcome in MGMT methylated cases results from enhanced sensitivity to alkylating agents or rather reflects a broader advantageous molecular profile of which $M G M T$ methylation is one part.

The "broader view" is supported by the observations that methylated tumors also draw benefit from radiation therapy alone [9-14] or from non-alkylating drugs [15]. For example, survival following radiotherapy alone in the EORTC-NCIC study was 15.3 months in methylated cases versus 11.8 months in unmethylated cases. It is possible that temozolomide administered for disease progression after radiotherapy in temozolomide-naïve patients may explain these results, at least in part. However, they also suggest that our understanding of the mechanism by which MGMT promoter methylation affects outcome is incomplete at this time. In addition, MGMT protein expression (technically AGT but MGMT is now widely adopted as the nomenclature for both gene and protein product) [16] does not correlate with temozolomide efficacy [17, 18], probably because of contamination by normal tissue, but also suggesting a more complex mechanism than simply MGMT gene silencing by promoter methylation. Finally, patients with tumors that do not exhibit a methylated promoter also survive longer following treatment with temozolomide and radiotherapy than radiotherapy alone at diagnosis [11].

Therefore, it appears that $M G M T$ methylation status is prognostic for survival regardless of therapy, and likely at least partially predictive of enhanced sensitivity to DNA alkylating chemotherapeutics. This has led some to advocate radiotherapy alone, without temozolomide, in patients with newly diagnosed GBM harboring unmethylated disease. It may be appropriate to modify therapy based on $M G M T$ status in a clinical trial, such as restricting entry to those with or without MGMT methylated tumor [15] as in the CENTRIC study (EORTC 26071-22072, NCT00689221). However, it should be noted that the current standard of care outside of a trial is radiotherapy and temozolomide regardless of MGMT status.

In the unmethylated setting, whether prolonged exposure to alkylating agents might deplete MGMT and thereby overcome MGMT mediated DNA repair mechanisms is an area of active investigation. Various alternative temozolomide dosing schedules are under investigation [19] some of which appear promising in early trials for newly diagnosed [20] and recurrent GBM [21-23]. These may prove superior to standard dosing, especially in cases without MGMT methylation, inferior, or equivalent with more or 
less toxicity. However, MGMT is not the only DNA repair mechanism of importance in gliomas. Accordingly, it is notable that the British Medical Research Council (MRC) trial BR12 of chemo-naive patients with recurrent highgrade gliomas did not demonstrate superior efficacy with dose-intense temozolomide $\left(100 \mathrm{mg} / \mathrm{m}^{2}, 21 / 28\right)$ versus standard dosing $\left(200 \mathrm{mg} / \mathrm{m}^{2}, 5 / 28\right)$ [24]. In fact, unexpectedly, progression-free survival favored standard dosing $(p=$ 0.023), and there was a trend toward favoring survival [24] (Michael Brada, personal communication). Radiation Therapy Oncology Group (RTOG) trial 0525 is a phase III study that randomized patients with newly diagnosed GBM to initiate either standard or dose-intense temozolomide after radiotherapy. Accrual is complete and results are pending. Another randomized trial dealing with a similar issue in recurrent GBMs is still accruing patients (DIRECTOR trial, conducted by the Neurooncology Working Group (NOA) of the German Cancer Society).

Elsewhere in this issue, Riemenschneider et al. [25] discuss analysis of and controversies surrounding MGMT methylation in more detail.

\section{1p19q co-deletion}

Approximately $5-10 \%$ of all primary brain tumors are oligodendrogliomas [26]. Loss of genetic material on the short (p) arm of chromosome 1 and the long (q) arm of chromosome 19, so-called chromosome 1p19q co-deletion, was first reported as an observation in oligodendroglial tumors in 1994 [27]. Cairncross et al. then reported chemosensitivity in patients with anaplastic oligodendrogliomas harboring deletion of $1 \mathrm{p}$ and particularly codeletion of $1 p$ and 19q [28]. Further study ensured, and it is now known that chromosomal loss results from an unbalanced translocation [29]. Nearly $85 \%$ of low-grade oligodendrogliomas and $65 \%$ of anaplastic oligodendrogliomas harbor $1 \mathrm{p} 19 \mathrm{q}$ co-deletion [30]. The higher frequency in lower grade tumors suggests deletion is an early event in tumor formation (J. Gregory Cairncross, personal communication). Indeed, observational studies suggest that co-deletion may be more common in cases of anaplastic oligodendroglial tumors with a prior history of low-grade glioma [31].

$1 \mathrm{p} 19 \mathrm{q}$ deletion status is frequently used to refine histologic diagnoses. The current World Health Organization (WHO) classification of gliomas is based on histopathology which divides gliomas into astrocytomas, oligodendrogliomas, and mixed oligo-astrocytomas as the most common subtypes [32]. However, histopathology alone does not identify molecular subtypes. For example, there is high inter-observer variation in diagnosing oligodendrogliomas [33], and expert panels often disagree [34-
38]. As $1 \mathrm{p} 19 \mathrm{q}$ co-deletion is most common in oligodendrogliomas, it is often used in the community and at academic centers to support a diagnosis of oligodendroglioma in cases with ambiguous histology [39]. However, molecular analysis alone is insufficient for diagnosis, and should be used to complement rather than replace classic histopathology $[34,36,39,40]$. Approximately $20 \%$ [41] of otherwise WHO grade IV tumors (GBMs) contain oligodendroglial features (termed GBM-O according to the most recent 2007 WHO classification) [32]. GBM-O likely harbors a higher frequency of $1 p$ and /or $19 q$ deletion than purely astrocytic GBM, but the reported frequencies vary from approximately $5 \%[42,43]$ to approximately $25 \%[44$, 45].

$1 \mathrm{p} 19 \mathrm{q}$ co-deletion is prognostic in anaplastic gliomas, validated in three randomized trials [14, 46, 47]. As a consequence, the two open phase III trials for anaplastic gliomas use both histology and deletion status as eligibility criteria. EORTC 26053-22054 (Concurrent and Adjuvant Temozolomide Chemotherapy for patients with NON$1 \mathrm{p} 19 \mathrm{q}$ deleted anaplastic glioma [CATNON] intergroup study) randomizes patients without $1 \mathrm{p} 19 \mathrm{q}$ co-deleted anaplastic gliomas to radiotherapy with or without concurrent and/or adjuvant temozolomide. NCCTG N057 (for $1 \mathrm{p} 19 \mathrm{q}$ co-deleted tumors, also called CODEL) will randomize patients with $1 \mathrm{p} 19 \mathrm{q}$ co-deleted anaplastic gliomas to radiotherapy, radiotherapy with concurrent and adjuvant temozolomide, or temozolomide. $1 \mathrm{p} 19 \mathrm{q}$ co-deletion is likely also prognostic for low-grade gliomas, but the data are less well defined. One study suggested that chromosome $1 p$ status is a significant prognostic marker in lowgrade gliomas regardless of histologic subtype [48]. A recently completed randomized trial of the EORTC 2203326033/NCIC in patients with WHO grade II gliomas stratified tumors by $1 \mathrm{p}$ status and will provide more information. There is inconsistency regarding the prognostic value of $1 p$ and $19 q$ deletion in GBMs with oligodendroglial features. For example, one study suggests that long-term survivors from GBM do not commonly harbor $1 \mathrm{p} 19 \mathrm{q}$ co-deletion [49]. However, $1 \mathrm{p}$ and $19 \mathrm{q}$ co-deletion is uncommon in GBMs as is long-term survival, making it difficult to address this issue definitively with sufficiently powered studies when clinical prognostic factors (e.g., age, extent of resection) are also considered [43, 45]. The variability observed in both deletion frequency and prognostic importance across studies may be explained at least in part by the histologic overlap between GBM-O and anaplastic oligodendroglioma, causing inclusion criteria inconsistencies. Finally, the prognostic significance of $19 q$ deletion without $1 p$ deletion, $1 p$ deletion without $19 q$ deletion, and $1 \mathrm{p} 19 \mathrm{q}$ co-deletion with other chromosomal abnormalities (such as $10 \mathrm{q}$ deletion or chromosome 7 gain) is not definitively understood with the existing data. 
Although $1 \mathrm{p} 19 \mathrm{q}$ co-deletion is clearly correlated with longer survival, it remains debated whether $1 \mathrm{p} 19 \mathrm{q}$ status should alter therapy. Of note, the favorable prognosis associated with $1 \mathrm{p} 19 \mathrm{q}$ co-deletion in oligodendroglial tumors may be reduced if no post-operative therapy is administered. In one study, after surgery alone, combined $1 \mathrm{p} 19 \mathrm{q}$ co-deletion was not prognostic for progression-free survival using multivariate analysis in a small number of patients with WHO grade II and III tumors [50]. This observation suggests that the mechanism by which $1 \mathrm{p} 19 \mathrm{q}$ co-deletion contributes to tumor biology may be through reduced expression of chemotherapy and/or radiotherapy resistance factors. Therefore, $1 \mathrm{p} 19 \mathrm{q}$ co-deletion may improve outcome only if surgery is followed by further therapy. However, others have reported opposing results [51], and selection bias is a potential confounder. Moreover, almost no neuro-oncologists would advocate observation for anaplastic oligodendroglial tumors regardless of $1 \mathrm{p} 19 \mathrm{q}$ status [52].

Regarding definitive therapy, the standard therapy for all WHO grade III-IV tumors, including anaplastic oligodendrogliomas, before the discovery of $1 \mathrm{p} 19 \mathrm{q}$ co-deletion was radiotherapy alone. This resulted from early multicenter studies conducted in the 1970s comparing radiotherapy with or without chemotherapy against chemotherapy alone or supportive care only [53,54]. These studies addressed whether radiotherapy improves survival in high-grade gliomas, as that was debated at the time. Although radiotherapy was clearly demonstrated as beneficial, these early studies did not distinguish among various high-grade glioma histologies and almost all patients enrolled had astrocytomas [55]. However, by the late 1980s and early 1990s reports emerged of exquisite chemosensitivity among both recurrent $[56,57]$ and newly diagnosed oligodendrogliomas [57, 58], especially those harboring $1 \mathrm{p} 19 \mathrm{q}$ codeletion [59]. Therefore, EORTC 26951 [47] and RTOG 9402 [46] were conceived as phase III randomized trials to evaluate the efficacy of adding chemotherapy (using procarbazine, lomustine, and vincristine collectively called $\mathrm{PCV}$ ) to radiotherapy in comparison to radiotherapy alone (then the standard). Both trials demonstrated, somewhat surprisingly, that overall survival was not prolonged by incorporating PCV into the up-front regimen, either immediately before [46] or after [47] radiotherapy. However, both trials also collected tissue used for $1 p 19 q$ analysis, and both demonstrated prolonged progressionfree survival following combined therapy in $1 p 19 q$ codeleted cases. The toxicity of PCV is substantial, and the intensified PCV regimen in RTOG 9402 (shorter cycles with higher doses of each agent) resulted in one fatal toxicity [46]. Accordingly, without a survival advantage, it is unclear whether the benefit of a longer progression-free interval outweighs the risks of potential toxicity. Of note, however, the median survival in the $1 \mathrm{p} 19 \mathrm{q}$ co-deleted cohort was not reached for patients treated with radiotherapy and intensive-PCV in RTOG 9402 as the survival curves began to separate [46], and further maturity of the data may well demonstrate a survival advantage on the experimental arm [60]. Longer follow up has not been conducted yet for EORTC 26951 (Martin J. van den Bent, personal communication).

Finally, the median survival of patients with anaplastic oligodendrogliomas is approximately 5 years [26], and longer for those harboring $1 \mathrm{p} 19 \mathrm{q}$ co-deletion. This is superior to the prognosis for astrocytomas of the same histologic grade [26]. Therefore, there is a small but real risk of delayed neuro-cognitive decline associated with early radiotherapy for anaplastic oligodendrogliomas, similar to that observed in long-term survivors of low-grade gliomas [61] or brain metastases [62]. This leads many neuro-oncologists, up to $42 \%$ in one survey, to advocate chemotherapy alone for newly diagnosed anaplastic oligodendrogliomas harboring $1 \mathrm{p} 19 \mathrm{q}$ deletion [52]. A retrospective study suggests deferring radiotherapy until first or later progression is reasonable in such patients [31]. A phase III prospective study by the Neurooncology Working Group (NOA) of the German Cancer Society (NOA-04) also suggests that initial chemotherapy is not inferior to radiotherapy in anaplastic gliomas [14] although the study design has been questioned [63]. The CODEL study will incorporate quality of life/neuro-cognitive endpoints to address some of these issues.

\section{IDH $1 / 2$ mutation}

Sequencing of the genome recently identified mutations in the isocitrate dehydrogenase 1 and 2 gene (IDH 1/2) that occur in the majority of WHO grade II-III gliomas and secondary GBMs [64, 65], all of which harbor a better prognosis compared to wild type cases [66]. A high frequency in low-grade gliomas and secondary GBMs suggests a role in early tumor development [64] similar to $1 \mathrm{p} 19 \mathrm{q}$ co-deletion in oligodendrogliomas. Therefore, it is not surprising that all $1 \mathrm{p} 19 \mathrm{q}$-deleted tumors apparently also harbor IDH1 or IDH2 mutations [67]. IDH appears to function as a tumor suppressor when inactivated through mutation [68], which causes the IDH enzyme to lose its ability to catalyze conversion of isocitrate to alphaketoglutarate and induces HIF1-alpha (hypoxia-inducible factor), which triggers the angiogenic process. However, the precise mechanism of its effect on tumor biology is currently unclear [68, 69].

IDH mutations occur in WHO grade II-IV tumors, and are not currently used to supplement classic histology. Yet, pilocytic astrocytomas (WHO grade I) that are potentially 
curable by complete resection, rarely harbor $I D H$ mutations. Occasionally they are difficult to distinguish histologically from diffuse infiltrating WHO grade II astrocytomas (with almost no curative potential). BRAF abnormalities that occur in $60-80 \%$ of pilocytic astrocytomas and almost never in diffuse astrocytomas seem to be helpful in this regard [70].

More importantly, the value of IDH 1/2 mutations relates to prognosis, as demonstrated in the German NOA 04 trial where patients with WHO grade III gliomas received primary radiotherapy or primary chemotherapy followed by cross-over at progression [14] and EORTC 26951 in which patients with anaplastic oligodendroglial tumors received primary radiotherapy alone or combined with PCV [71]. Both studies demonstrated longer survival correlated with IDH mutation. A French series also demonstrated that $I D H 1$ mutations independently predicted longer survival for patients with both low- and high-grade gliomas [66]. Others reported analogous prognostic value across glioma grades [64], and also observed that $100 \%$ of $1 \mathrm{p} 19 \mathrm{q}$ deleted tumors harbor mutations in $I D H 1$ or $I D H 2$ [72].

At this time, IDH mutations do not appear predictive for outcome to a specific therapy. However, our understanding of the interplay between $I D H$ mutation and oncogenesis is currently limited.

\section{EGFR mutation}

EGFR was among the first cell-surface glycoproteins recognized as amplified and re-arranged in GBM and acting as an oncogene. Many GBMs exhibiting EGFR amplification have EGFR mutations, most commonly the variant 3 (EGFRvIII) (approximately 40\%), which is truly tumor-specific and results from deletion of exons 2-7 leading to constitutive receptor activity [73].

$E G F R$ amplification and mutation define a distinct subset of tumors. EGFR abnormalities are typically associated with GBM and anaplastic astrocytoma rather than oligodendrogliomas [74, 75]. This observation may help to refine histologic diagnosis in ambiguous cases.

The prognostic relevance of EGFR amplification and EGFRvIII mutation in GBM remain controversial. Tumors expressing EGFRvIII behaved more aggressively in one study, but only when other prognostic factors were considered [76]. In a population-based study, the presence of EGFR amplification did not significantly affect survival of patients with GBM at any age [77]. The prognostic importance of EGFR abnormalities is inconclusive at this time, with conflicting data as reviewed elsewhere [77, 78].

Similarly, whether therapy should be tailored based on presence or absence of EGFR amplification or mutation is an area of active study. Available data is insufficient to guide management decisions outside of a clinical trial. EGFRvIII-expressing tumor cells are an ideal target for passive and active immunotherapy as the mutation does not occur in normal glia. Trials with various vaccination approaches are underway with promising early results [79], but selection bias (i.e., exclusion of patients with less than gross-total resection) and accrual are challenges to interpretation and study completion.

EGFR tyrosine kinase inhibitors (TKIs) have been studied in multiple trials, typically for recurrent GBM with almost universally negative results [80-85]. Poor efficacy may result from inadequate drug penetration into brain tumor tissue of erlotinib at standard dosing [86, 87]. Gefitinib may have superior penetration [86, 88] but is unavailable in the United States. Lapatinib also may become sequestered in brain tumor tissue [89], but has been studied in gliomas less extensively than other EGFR TKIs.

It is controversial whether EGFR amplification or mutation predicts sensitivity to EGFR TKIs, presuming adequate drug delivery. One retrospective analysis of pretreatment tissue from patients prospectively enrolled in multicenter phase I/II studies demonstrated that EGFRvIII mutation in the setting of retained expression of its downstream mediator, phosphatase and tensin homolog on chromosome ten (PTEN), strongly predicted radiographic response of recurrent malignant gliomas to erlotinib and gefitinib [6]. Another study similarly demonstrated EGFR overexpression/amplification and reduced AKT activity (which results from PTEN retention) were predictive of erlotinib response [90]. A case report also suggests that this molecular signature is predictive of response [91]. However, others have questioned these results [92]. For example, a prospective trial (EORTC 26034) did not find EGFRvIII or PTEN to correlate with clinical benefit [93]. The discrepancy in findings may result from lack of uniformity in defining both clinical efficacy (e.g., 6-month progressionfree survival versus response rate as well as differing criteria for designation of radiographic response) and scoring of EGFR/PTEN anomalies in human tumor samples. In addition, all of these studies used a similar design - to enroll patients without regard to molecular information and then retrospectively correlate EGFR and PTEN anomalies with clinical outcome. The frequency of EGFRvIII and PTEN co-expression is so low (approximately $5-10 \%$ of cases in our experience) that a prospective trial exclusively for patients harboring tumors with such a molecular profile is impractical. Moreover, neither EGFR amplification, nor EGFRvIII mutational analysis, nor PTEN analysis is routinely available at most centers. A planned prospective study of EGFR tyrosine kinase inhibition will require the presence of EGFRvIII mutation for eligibility 
and use a different erlotinib dosing schedule than previously administered [87] for gliomas to potentially overcome resistance mediated by PTEN loss.

\section{Conclusions}

Diagnostic and prognostic markers are increasingly implemented in neuro-oncology as decision-making tools toward more objective classification of gliomas, to prognosticate, and to guide therapy. $1 \mathrm{p} 19 \mathrm{q}$ co-deletion supplements classic histology to clarify a diagnosis of oligodendroglioma. By contrast, EGFR abnormalities are most common in astrocytomas. The prognostic value of various markers is well established, although their predictive value in guiding specific therapy is an area of active research. For example, $M G M T$ promoter methylation, $1 \mathrm{p} 19 \mathrm{q}$ co-deletion, and $I D H$ 1/2- mutation each indicate a more favorable disease outcome independent of the type of therapy. This holds true for WHO grade II-IV gliomas, except perhaps for an unclear significance of 1p19q co-deletion in GBMs. In clinical trials, accrual must be stratified accordingly in order to avoid biasing results.

Linkage of "favourable prognosis" markers, or a "hierarchy", is still not well understood. However, 1p19q co-deletion seems to occur exclusively of EGFR abnormalities [75] but co-segregates with IDH mutation [67]. Moreover, in oligodendroglial tumours there is a strong correlation between the presence of $M G M T$ promoter methylation, $1 \mathrm{p} 19 \mathrm{q}$ co-deletion, and $I D H 1 / 2$ mutation, at least in anaplastic disease [13, 14, 71, 72]. Data in GBMs are less clear [18]. Whether the underlying mechanisms act independently or together remains to be investigated.

It is tempting to speculate that patients with tumors that harbor poor prognostic molecular markers (e.g., unmethylated MGMT promoter, wild type IDH1 and IDH2, lack of $1 \mathrm{p} 19 \mathrm{q}$ deletion) should be treated more intensely. One example is incorporation of bevacizumab, approved for treatment of recurrent GBM in the United States and Switzerland, into the treatment administered at diagnosis, although benefit at recurrence is still debated [94]. Ongoing GBM trials (RTOG 0825, AVAGLIO) will address this issue. However, more is not necessarily better, and it is unclear whether more aggressive therapy improves survival for such patients or only risks additional toxicity [95]. For example, in anaplastic oligodendroglial tumors without $1 \mathrm{p} 19 \mathrm{q}$ co-deletion, there was neither a progression-free survival nor overall survival benefit for radiotherapy and PCV versus radiotherapy alone in one randomized phase III trial (RTOG 9402) [46].

Therefore, to date there is no validated predictive biomarker to accurately guide a clinician in deciding treatment in routine practice. However, this remains an area of active investigation and multiple clinical trials are incorporating molecular information into their design, either as stratification factors to balance treatment arms in randomized studies, or as eligibility criteria.

Acknowledgements We thank Judith Lampron for invaluable expert editorial assistance and Ingo Mellinghoff for critical review of the manuscript.

Conflict of interest statement No funds were received in support of this study.

\section{References}

1. Phillips HS, Kharbanda S, Chen R, Forrest WF, Soriano RH, Wu TD, Misra A, Nigro JM, Colman H, Soroceanu L, Williams PM, Modrusan Z, Feuerstein BG, Aldape K (2006) Molecular subclasses of high-grade glioma predict prognosis, delineate a pattern of disease progression, and resemble stages in neurogenesis. Cancer Cell 9:157-173

2. Cancer Genome Atlas Research Network (2008) Comprehensive genomic characterization defines human glioblastoma genes and core pathways. Nature 455:1061-1068

3. Curran WJ Jr, Scott CB, Horton J, Nelson JS, Weinstein AS, Fischbach AJ, Chang CH, Rotman M, Asbell SO, Krisch RE et al (1993) Recursive partitioning analysis of prognostic factors in three Radiation Therapy Oncology Group malignant glioma trials. J Natl Cancer Inst 85:704-710

4. Mirimanoff RO, Gorlia T, Mason W, Van den Bent MJ, Kortmann RD, Fisher B, Reni M, Brandes AA, Curschmann J, Villa S, Cairncross G, Allgeier A, Lacombe D, Stupp R (2006) Radiotherapy and temozolomide for newly diagnosed glioblastoma: recursive partitioning analysis of the EORTC 26981/22981-NCIC CE3 phase III randomized trial. J Clin Oncol 24:2563-2569

5. Scott CB, Scarantino C, Urtasun R, Movsas B, Jones CU, Simpson JR, Fischbach AJ, Curran WJ Jr (1998) Validation and predictive power of Radiation Therapy Oncology Group (RTOG) recursive partitioning analysis classes for malignant glioma patients: a report using RTOG 90-06. Int J Radiat Oncol Biol Phys 40:51-55

6. Mellinghoff IK, Wang MY, Vivanco I, Haas-Kogan DA, Zhu S, Dia EQ, Lu KV, Yoshimoto K, Huang JH, Chute DJ, Riggs BL, Horvath S, Liau LM, Cavenee WK, Rao PN, Beroukhim R, Peck TC, Lee JC, Sellers WR, Stokoe D, Prados M, Cloughesy TF, Sawyers CL, Mischel PS (2005) Molecular determinants of the response of glioblastomas to EGFR kinase inhibitors. N Engl J Med 353:2012-2024

7. Lee JC, Vivanco I, Beroukhim R, Huang JH, Feng WL, DeBiasi RM, Yoshimoto K, King JC, Nghiemphu P, Yuza Y, Xu Q, Greulich H, Thomas RK, Paez JG, Peck TC, Linhart DJ, Glatt KA, Getz G, Onofrio R, Ziaugra L, Levine RL, Gabriel S, Kawaguchi T, O’Neill K, Khan H, Liau LM, Nelson SF, Rao PN, Mischel P, Pieper RO, Cloughesy T, Leahy DJ, Sellers WR, Sawyers CL, Meyerson M, Mellinghoff IK (2006) Epidermal growth factor receptor activation in glioblastoma through novel missense mutations in the extracellular domain. PLoS Med 3:e485

8. Everhard S, Kaloshi G, Criniere E, Benouaich-Amiel A, Lejeune J, Marie Y, Sanson M, Kujas M, Mokhtari K, Hoang-Xuan K, Delattre JY, Thillet J (2006) MGMT methylation: a marker of response to temozolomide in low-grade gliomas. Ann Neurol 60:740-743

9. Hegi ME, Diserens AC, Gorlia T, Hamou MF, de Tribolet N, Weller M, Kros JM, Hainfellner JA, Mason W, Mariani L, Bromberg JE, Hau P, Mirimanoff RO, Cairncross JG, Janzer RC, 
Stupp R (2005) MGMT gene silencing and benefit from temozolomide in glioblastoma. N Engl J Med 352:997-1003

10. Stupp R, Mason WP, van den Bent MJ, Weller M, Fisher B, Taphoorn MJ, Belanger K, Brandes AA, Marosi C, Bogdahn U, Curschmann J, Janzer RC, Ludwin SK, Gorlia T, Allgeier A, Lacombe D, Cairncross JG, Eisenhauer E, Mirimanoff RO (2005) Radiotherapy plus concomitant and adjuvant temozolomide for glioblastoma. N Engl J Med 352:987-996

11. Stupp R, Hegi ME, Mason WP, van den Bent MJ, Taphoorn MJ, Janzer RC, Ludwin SK, Allgeier A, Fisher B, Belanger K, Hau P, Brandes AA, Gijtenbeek J, Marosi C, Vecht CJ, Mokhtari K, Wesseling P, Villa S, Eisenhauer E, Gorlia T, Weller M, Lacombe D, Cairncross JG, Mirimanoff RO (2009) Effects of radiotherapy with concomitant and adjuvant temozolomide versus radiotherapy alone on survival in glioblastoma in a randomised phase III study: 5-year analysis of the EORTC-NCIC trial. Lancet Oncol 10:459466

12. Rivera AL, Pelloski CE, Gilbert MR, Colman H, De La Cruz C, Sulman EP, Bekele BN, Aldape KD (2010) MGMT promoter methylation is predictive of response to radiotherapy and prognostic in the absence of adjuvant alkylating chemotherapy for glioblastoma. Neuro Oncol 12:116-121

13. van den Bent MJ, Dubbink HJ, Sanson M, van der Lee-Haarloo CR, Hegi M, Jeuken JW, Ibdaih A, Brandes AA, Taphoorn MJ, Frenay M, Lacombe D, Gorlia T, Dinjens WN, Kros JM (2009) MGMT promoter methylation is prognostic but not predictive for outcome to adjuvant PCV chemotherapy in anaplastic oligodendroglial tumors: a report from EORTC Brain Tumor Group Study 26951. J Clin Oncol 27:5881-5886

14. Wick W, Hartmann C, Engel C, Stoffels M, Felsberg J, Stockhammer F, Sabel MC, Koeppen S, Ketter R, Meyermann R, Rapp M, Meisner C, Kortmann RD, Pietsch T, Wiestler OD, Ernemann U, Bamberg M, Reifenberger G, von Deimling A, Weller M (2009) NOA-04 randomized phase III trial of sequential radiochemotherapy of anaplastic glioma with procarbazine, lomustine, and vincristine or temozolomide. J Clin Oncol 27:5874-5880

15. Stupp R, Hegi ME, Neyns B, Goldbrunner R, Schlegel U, Clement PM, Grabenbauer GG, Ochsenbein AF, Simon M, Dietrich PY, Pietsch T, Hicking C, Tonn JC, Diserens AC, Pica A, Hermisson M, Krueger S, Picard M, Weller M (2010) Phase I/ IIa study of cilengitide and temozolomide with concomitant radiotherapy followed by cilengitide and temozolomide maintenance therapy in patients with newly diagnosed glioblastoma. J Clin Oncol 28(16):2712-2718

16. Gerson SL (2004) MGMT: its role in cancer aetiology and cancer therapeutics. Nat Rev Cancer 4:296-307

17. Preusser M, Charles Janzer R, Felsberg J, Reifenberger G, Hamou MF, Diserens AC, Stupp R, Gorlia T, Marosi C, Heinzl H, Hainfellner JA, Hegi M (2008) Anti-O6-methylguanine-methyltransferase (MGMT) immunohistochemistry in glioblastoma multiforme: observer variability and lack of association with patient survival impede its use as clinical biomarker. Brain Pathol 18:520-532

18. Felsberg J, Rapp M, Loeser S, Fimmers R, Stummer W, Goeppert M, Steiger HJ, Friedensdorf B, Reifenberger G, Sabel MC (2009) Prognostic significance of molecular markers and extent of resection in primary glioblastoma patients. Clin Cancer Res 15:6683-6693

19. Wick W, Platten M, Weller M (2009) New (alternative) temozolomide regimens for the treatment of glioma. Neuro Oncol 11:69-79

20. Clarke JL, Iwamoto FM, Sul J, Panageas K, Lassman AB, DeAngelis LM, Hormigo A, Nolan CP, Gavrilovic I, Karimi S, Abrey LE (2009) Randomized phase II trial of chemoradiotherapy followed by either dose-dense or metronomic temozolomide for newly diagnosed glioblastoma. J Clin Oncol 27:3861-3867
21. Perry JR, Belanger K, Mason WP, Fulton D, Kavan P, Easaw J, Shields C, Kirby S, Macdonald DR, Eisenstat DD, Thiessen B, Forsyth P, Pouliot JF (2010) Phase II trial of continuous doseintense temozolomide in recurrent malignant glioma: RESCUE study. J Clin Oncol 28:2051-2057

22. Kong DS, Lee JI, Kim JH, Kim ST, Kim WS, Suh YL, Dong SM, Nam DH (2010) Phase II trial of low-dose continuous (metronomic) treatment of temozolomide for recurrent glioblastoma. Neuro Oncol 12:289-296

23. Wick W, Steinbach JP, Kuker WM, Dichgans J, Bamberg M, Weller M (2004) One week on/one week off: a novel active regimen of temozolomide for recurrent glioblastoma. Neurology 62:2113-2115

24. Brada M, for the BR12 collaborators (2008) A randomised trial of Procarbazine, CCNU and Vincristine (PCV) vs. Temozolomide (5-day or 21-day schedule) for recurrent high-grade glioma (MRC BR12) [Abstract O21]. Neuro Oncol 10:1067

25. Riemenschneider MJ, Hegi ME, Reifenberger G (2010) MGMT promoter methylation in malignant gliomas. Targ Oncol, in press. doi:10.1007/s11523-010-0153-6

26. CBTRUS: Central Brain Tumor Registry of the United States 2008 statistical report: primary brain tumors in the Uninted States. www.cbtrus.org/reports/reports.html. Accessed August 12, 2010

27. Reifenberger J, Reifenberger G, Liu L, James CD, Wechsler W, Collins VP (1994) Molecular genetic analysis of oligodendroglial tumors shows preferential allelic deletions on $19 q$ and $1 p$. Am J Pathol 145:1175-1190

28. Cairncross JG, Ueki K, Zlatescu MC, Lisle DK, Finkelstein DM, Hammond RR, Silver JS, Stark PC, Macdonald DR, Ino Y, Ramsay DA, Louis DN (1998) Specific genetic predictors of chemotherapeutic response and survival in patients with anaplastic oligodendrogliomas. J Natl Cancer Inst 90:1473-1479

29. Jenkins RB, Blair H, Ballman KV, Giannini C, Arusell RM, Law M, Flynn H, Passe S, Felten S, Brown PD, Shaw EG, Buckner JC (2006) A t $(1 ; 19)(q 10 ; p 10)$ mediates the combined deletions of $1 p$ and $19 \mathrm{q}$ and predicts a better prognosis of patients with oligodendroglioma. Cancer Res 66:9852-9861

30. Smith JS, Perry A, Borell TJ, Lee HK, O'Fallon J, Hosek SM, Kimmel D, Yates A, Burger PC, Scheithauer BW, Jenkins RB (2000) Alterations of chromosome arms $1 p$ and $19 q$ as predictors of survival in oligodendrogliomas, astrocytomas, and mixed oligoastrocytomas. J Clin Oncol 18:636-645

31. Lassman AB, Panageas KS, Iwamoto FM, DeAngelis LM, Rivera AL, Aldape KD, Cloughesy TF, Eichler A, Louis DN, Paleologos N, Fisher B, Ashby L, Roldan GB, Cairncross JG, Wen PY, Schiff D, Rocque BG, Robins HI, Chamberlain MC, Mason W, Weaver S, Green RM, Kamar FG, Jhanwar S, Rosenblum MK, Abrey LE (2009) International retrospective study of $1000+$ adults with anaplastic oligodendroglial tumors [Abstract 283]. Neuro Oncol 11:629

32. Louis DN, Ohgaki H, Wiestler OD et al (2007) The 2007 WHO Classification of Tumours of the Central Nervous System. Acta Neuropathol 114(2):97-109

33. Burger PC (2002) What is an oligodendroglioma? Brain Pathol $12: 257-259$

34. Giannini C, Burger PC, Berkey BA, Cairncross JG, Jenkins RB, Mehta M, Curran WJ, Aldape K (2008) Anaplastic oligodendroglial tumors: refining the correlation among histopathology, $1 \mathrm{p} 19 \mathrm{q}$ deletion and clinical outcome in Intergroup Radiation Therapy Oncology Group Trial 9402. Brain Pathol 18:360-369

35. Giannini C, Scheithauer BW, Weaver AL, Burger PC, Kros JM, Mork S, Graeber MB, Bauserman S, Buckner JC, Burton J, Riepe R, Tazelaar HD, Nascimento AG, Crotty T, Keeney GL, Pernicone P, Altermatt H (2001) Oligodendrogliomas: reproducibility and prognostic value of histologic diagnosis and grading. J Neuropathol Exp Neurol 60:248-262 
36. McDonald JM, See SJ, Tremont IW, Colman H, Gilbert MR, Groves M, Burger PC, Louis DN, Giannini C, Fuller G, Passe S, Blair H, Jenkins RB, Yang H, Ledoux A, Aaron J, Tipnis U, Zhang W, Hess K, Aldape K (2005) The prognostic impact of histology and $1 \mathrm{p} / 19 \mathrm{q}$ status in anaplastic oligodendroglial tumors. Cancer 104:1468-1477

37. Coons SW, Johnson PC, Scheithauer BW, Yates AJ, Pearl DK (1997) Improving diagnostic accuracy and interobserver concordance in the classification and grading of primary gliomas. Cancer 79:1381-1393

38. Kros J, Gorlia T, van den Bent M (2007) Panel review of anaplastic oligodendroglioma from EORTC trial 26951: consensus in diagnosis and influence of $1 \mathrm{p} / 19 \mathrm{q}$ [abstract PA-16]. Neuro Oncol 9:545

39. Aldape K, Burger PC, Perry A (2007) Clinicopathologic aspects of $1 \mathrm{p} / 19 \mathrm{q}$ loss and the diagnosis of oligodendroglioma. Arch Pathol Lab Med 131:242-251

40. Kouwenhoven K, Gorlia T, Kros J, Carpentier A, Brandes A, Sanson M, Taphoorn M, Teepen H, Bernsen H, Frenay M, Tijssen C, Grisold W, Sipos L, Stupp R, Vecht C, Allgeier A, Lacombe D, van den Bent M (2007) EORTC 26951: prognosis of oligodendroglial tumors is an interplay of molecular, histological, and clinical characteristics [abstract PA-18]. Neuro Oncol 9:546

41. Homma T, Fukushima T, Vaccarella S, Yonekawa Y, Di Patre PL, Franceschi S, Ohgaki H (2006) Correlation among pathology, genotype, and patient outcomes in glioblastoma. J Neuropathol Exp Neurol 65:846-854

42. Pinto LW, Araujo MB, Vettore AL, Wernersbach L, Leite AC, Chimelli LM, Soares FA (2008) Glioblastomas: correlation between oligodendroglial components, genetic abnormalities, and prognosis. Virchows Arch 452:481-490

43. Kraus JA, Lamszus K, Glesmann N, Beck M, Wolter M, Sabel M, Krex D, Klockgether T, Reifenberger G, Schlegel U (2001) Molecular genetic alterations in glioblastomas with oligodendroglial component. Acta Neuropathol 101:311-320

44. Bigner SH, Matthews MR, Rasheed BK, Wiltshire RN, Friedman HS, Friedman AH, Stenzel TT, Dawes DM, McLendon RE, Bigner DD (1999) Molecular genetic aspects of oligodendrogliomas including analysis by comparative genomic hybridization. Am J Pathol 155:375-386

45. He J, Mokhtari K, Sanson M, Marie Y, Kujas M, Huguet S, Leuraud P, Capelle L, Delattre JY, Poirier J, Hoang-Xuan K (2001) Glioblastomas with an oligodendroglial component: a pathological and molecular study. J Neuropathol Exp Neurol 60:863-871

46. Cairncross G, Berkey B, Shaw E, Jenkins R, Scheithauer B, Brachman D, Buckner J, Fink K, Souhami L, Laperierre N, Mehta M, Curran W (2006) Phase III trial of chemotherapy plus radiotherapy compared with radiotherapy alone for pure and mixed anaplastic oligodendroglioma: Intergroup Radiation Therapy Oncology Group Trial 9402. J Clin Oncol 24:2707-2714

47. van den Bent MJ, Carpentier AF, Brandes AA, Sanson M, Taphoorn MJ, Bernsen HJ, Frenay M, Tijssen CC, Grisold W, Sipos L, Haaxma-Reiche H, Kros JM, van Kouwenhoven MC, Vecht CJ, Allgeier A, Lacombe D, Gorlia T (2006) Adjuvant procarbazine, lomustine, and vincristine improves progressionfree survival but not overall survival in newly diagnosed anaplastic oligodendrogliomas and oligoastrocytomas: a randomized European Organisation for Research and Treatment of Cancer phase III trial. J Clin Oncol 24:2715-2722

48. Iwamoto FM, Nicolardi L, Demopoulos A, Barbashina V, Salazar P, Rosenblum M, Hormigo A (2008) Clinical relevance of $1 p$ and $19 \mathrm{q}$ deletion for patients with WHO grade 2 and 3 gliomas. J Neurooncol 88:293-298

49. Krex D, Klink B, Hartmann C, von Deimling A, Pietsch T, Simon M, Sabel M, Steinbach JP, Heese O, Reifenberger G, Weller M,
Schackert G (2007) Long-term survival with glioblastoma multiforme. Brain 130:2596-2606

50. Weller M, Berger H, Hartmann C, Schramm J, Westphal M, Simon M, Goldbrunner R, Krex D, Steinbach JP, Ostertag CB, Loeffler M, Pietsch T, von Deimling A (2007) Combined 1p/19q loss in oligodendroglial tumors: predictive or prognostic biomarker? Clin Cancer Res 13:6933-6937

51. van den Bent MJ, Looijenga LH, Langenberg K, Dinjens W, Graveland W, Uytdewilligen L, Sillevis Smitt PA, Jenkins RB, Kros JM (2003) Chromosomal anomalies in oligodendroglial tumors are correlated with clinical features. Cancer 97:1276-1284

52. Abrey LE, Louis DN, Paleologos N, Lassman AB, Raizer JJ, Mason W, Finlay J, Macdonald DR, Deangelis LM, Cairncross JG (2007) Survey of treatment recommendations for anaplastic oligodendroglioma. Neuro-oncol 9:314-318

53. Walker MD, Alexander E Jr, Hunt WE, MacCarty CS, Mahaley MS Jr, Mealey J Jr, Norrell HA, Owens G, Ransohoff J, Wilson CB, Gehan EA, Strike TA (1978) Evaluation of BCNU and/or radiotherapy in the treatment of anaplastic gliomas. A cooperative clinical trial. J Neurosurg 49:333-343

54. Walker MD, Green SB, Byar DP, Alexander E Jr, Batzdorf U, Brooks WH, Hunt WE, MacCarty CS, Mahaley MS Jr, Mealey J Jr, Owens G, Ransohoff J 2nd, Robertson JT, Shapiro WR, Smith KR Jr, Wilson CB, Strike TA (1980) Randomized comparisons of radiotherapy and nitrosoureas for the treatment of malignant glioma after surgery. N Engl J Med 303:1323-1329

55. DeAngelis LM, Burger PC, Green SB, Cairncross JG (1998) Malignant glioma: who benefits from adjuvant chemotherapy? Ann Neurol 44:691-695

56. Cairncross JG, Macdonald DR (1988) Successful chemotherapy for recurrent malignant oligodendroglioma. Ann Neurol 23:360364

57. Cairncross G, Macdonald D, Ludwin S, Lee D, Cascino T, Buckner J, Fulton D, Dropcho E, Stewart D, Schold C Jr et al (1994) Chemotherapy for anaplastic oligodendroglioma. National Cancer Institute of Canada Clinical Trials Group. J Clin Oncol 12:2013-2021

58. Macdonald DR, Gaspar LE, Cairncross JG (1990) Successful chemotherapy for newly diagnosed aggressive oligodendroglioma. Ann Neurol 27:573-574

59. Ino Y, Betensky RA, Zlatescu MC, Sasaki H, Macdonald DR, Stemmer-Rachamimov AO, Ramsay DA, Cairncross JG, Louis DN (2001) Molecular subtypes of anaplastic oligodendroglioma: implications for patient management at diagnosis. Clin Cancer Res 7:839-845

60. Cairncross G, Wang M, Chang S, Shaw E, Jenkins R, Scheithauer B, Buckner J, Fink K, Mehta M, Curran W (2008) A randomized trial of chemotherapy plus radiotherapy (RT) versus RT alone for anaplastic oligodendroglioma (RTOG 9402): the perspective of longer follow-up. Int J Rad Oncol Bio Phys 72:S7-S8

61. Douw L, Klein M, Fagel SS, van den Heuvel J, Taphoorn MJ, Aaronson NK, Postma TJ, Vandertop WP, Mooij JJ, Boerman RH, Beute GN, Sluimer JD, Slotman BJ, Reijneveld JC, Heimans JJ (2009) Cognitive and radiological effects of radiotherapy in patients with low-grade glioma: long-term follow-up. Lancet Neurol 8:810-818

62. DeAngelis LM, Delattre JY, Posner JB (1989) Radiation-induced dementia in patients cured of brain metastases. Neurology 39:789-796

63. DeAngelis LM (2009) Anaplastic glioma: how to prognosticate outcome and choose a treatment strategy. [corrected]. J Clin Oncol 27:5861-5862

64. Yan H, Parsons DW, Jin G, McLendon R, Rasheed BA, Yuan W, Kos I, Batinic-Haberle I, Jones S, Riggins GJ, Friedman H, Friedman A, Reardon D, Herndon J, Kinzler KW, Velculescu VE, 
Vogelstein B, Bigner DD (2009) IDH1 and IDH2 mutations in gliomas. N Engl J Med 360:765-773

65. Hartmann C, Meyer J, Balss J, Capper D, Mueller W, Christians A, Felsberg J, Wolter M, Mawrin C, Wick W, Weller M, HeroldMende C, Unterberg A, Jeuken JW, Wesseling P, Reifenberger G, von Deimling A (2009) Type and frequency of IDH1 and IDH2 mutations are related to astrocytic and oligodendroglial differentiation and age: a study of 1, 010 diffuse gliomas. Acta Neuropathol 118:469-474

66. Sanson M, Marie Y, Paris S, Idbaih A, Laffaire J, Ducray F, El Hallani S, Boisselier B, Mokhtari K, Hoang-Xuan K, Delattre JY (2009) Isocitrate dehydrogenase 1 codon 132 mutation is an important prognostic biomarker in gliomas. J Clin Oncol $27: 4150-4154$

67. Labussiere M, Idbaih A, Wang XW, Marie Y, Boisselier B, Falet C, Paris S, Laffaire J, Carpentier C, Criniere E, Ducray F, El Hallani S, Mokhtari K, Hoang-Xuan K, Delattre JY, Sanson M (2010) All the $1 p 19 q$ codeleted gliomas are mutated on IDH1 or IDH2. Neurology 74:1886-1890

68. Zhao S, Lin Y, Xu W, Jiang W, Zha Z, Wang P, Yu W, Li Z, Gong L, Peng Y, Ding J, Lei Q, Guan KL, Xiong Y (2009) Gliomaderived mutations in IDH1 dominantly inhibit IDH1 catalytic activity and induce HIF-1alpha. Science 324:261-265

69. Dang L, White DW, Gross S, Bennett BD, Bittinger MA, Driggers EM, Fantin VR, Jang HG, Jin S, Keenan MC, Marks KM, Prins RM, Ward PS, Yen KE, Liau LM, Rabinowitz JD, Cantley LC, Thompson CB, Vander Heiden MG, Su SM (2009) Cancerassociated IDH1 mutations produce 2-hydroxyglutarate. Nature 462:739-744

70. Korshunov A, Meyer J, Capper D, Christians A, Remke M, Witt H, Pfister S, von Deimling A, Hartmann C (2009) Combined molecular analysis of BRAF and IDH1 distinguishes pilocytic astrocytoma from diffuse astrocytoma. Acta Neuropathol 118:401-405

71. van den Bent MJ, Dubbink HJ, Marie Y, Brandes AA, Taphoorn MJ, Wesseling P, Frenay M, Tijssen CC, Lacombe D, Idbaih A, van Marion R, Kros JM, Dinjens WN, Gorlia T, Sanson M (2010) IDH1 and IDH2 mutations are prognostic but not predictive for outcome in anaplastic oligodendroglial tumors: a report of the European Organization for Research and Treatment of Cancer Brain Tumor Group. Clin Cancer Res 16:1597-1604

72. Labussiere M, Idbaih A, Wang XW, Marie Y, Boisselier B, Falet C, Paris S, Laffaire J, Carpentier C, Criniere E, Ducray F, El Hallani S, Mokhtari K, Hoang-Xuan K, Delattre JY, Sanson M (2010) All the 1p19q codeleted gliomas are mutated on IDH1 or IDH2. Neurology 74:1886-1890

73. Kuan CT, Wikstrand CJ, Bigner DD (2001) EGF mutant receptor vIII as a molecular target in cancer therapy. Endocr Relat Cancer 8:83-96

74. Fallon KB, Palmer CA, Roth KA, Nabors LB, Wang W, Carpenter M, Banerjee R, Forsyth P, Rich K, Perry A (2004) Prognostic value of 1p, 19q, 9p, 10q, and EGFR-FISH analyses in recurrent oligodendrogliomas. J Neuropathol Exp Neurol 63:314-322

75. Hoang-Xuan K, He J, Huguet S, Mokhtari K, Marie Y, Kujas M, Leuraud P, Capelle L, Delattre JY, Poirier J, Broet P, Sanson M (2001) Molecular heterogeneity of oligodendrogliomas suggests alternative pathways in tumor progression. Neurology 57:12781281

76. Pelloski CE, Ballman KV, Furth AF, Zhang L, Lin E, Sulman EP, Bhat $\mathrm{K}$, McDonald JM, Yung WK, Colman H, Woo SY, Heimberger AB, Suki D, Prados MD, Chang SM, Barker FG 2nd, Buckner JC, James CD, Aldape K (2007) Epidermal growth factor receptor variant III status defines clinically distinct subtypes of glioblastoma. J Clin Oncol 25:2288-2294

77. Ohgaki H, Dessen P, Jourde B, Horstmann S, Nishikawa T, Di Patre PL, Burkhard C, Schuler D, Probst-Hensch NM, Maiorka
PC, Baeza N, Pisani P, Yonekawa Y, Yasargil MG, Lutolf UM, Kleihues P (2004) Genetic pathways to glioblastoma: a population-based study. Cancer Res 64:6892-6899

78. Liu L, Bäcklund LM, Nilsson BR, Grandér D, Ichimura K, Goike HM, Collins VP (2005) Clinical significance of EGFR amplification and the aberrant EGFRvIII transcript in conventionally treated astrocytic gliomas. J Mol Med 83(11):917-926

79. Lai R, Recht LD, Reardon DA, Paleologos N, Groves MD, Rosenfeld MR, Meech S, Davis TA, Pavlov D, Sampson JH (2010) Interim data for ACT III: Phase II trial of PF-04948568 (CDX-110) in combination with temozolomide (TMZ) in patients (pts) with glioblastoma (GBM) [Abstract]. J Clin Oncol 28: suppl; abstract 2014

80. Raizer JJ, Abrey LE, Lassman AB, Chang SM, Lamborn KR, Kuhn JG, Yung WK, Gilbert MR, Aldape KA, Wen PY, Fine HA, Mehta M, Deangelis LM, Lieberman F, Cloughesy TF, Robins HI, Dancey J, Prados MD (2010) A phase II trial of erlotinib in patients with recurrent malignant gliomas and nonprogressive glioblastoma multiforme postradiation therapy. Neuro Oncol 12:95-103

81. Lieberman FS, Cloughesy T, Malkin M, Fine H, Fink K, Junck L, Kuhn J, Mehta M, Wen P, Prados M (2003) Phase I-II study of ZD-1839 for recurrent malignant gliomas and meningiomas progressing after radiation therapy [abstract]. J Clin Oncol 22:105 (abstact 421)

82. Rich JN, Reardon DA, Peery T, Dowell JM, Quinn JA, Penne KL, Wikstrand CJ, Van Duyn LB, Dancey JE, McLendon RE, Kao JC, Stenzel TT, Ahmed Rasheed BK, Tourt-Uhlig SE, Herndon JE 2nd, Vredenburgh JJ, Sampson JH, Friedman AH, Bigner DD, Friedman HS (2004) Phase II trial of gefitinib in recurrent glioblastoma. J Clin Oncol 22:133-142

83. Peereboom DM, Shepard DR, Ahluwalia MS, Brewer CJ, Agarwal N, Stevens GH, Suh JH, Toms SA, Vogelbaum MA, Weil RJ, Elson P, Barnett GH (2010) Phase II trial of erlotinib with temozolomide and radiation in patients with newly diagnosed glioblastoma multiforme. J Neurooncol 98:93-99

84. Yung WK, Vredenburgh JJ, Cloughesy TF, Nghiemphu P, Klencke B, Gilbert MR, Reardon DA, Prados MD (2010) Safety and efficacy of erlotinib in first-relapse glioblastoma: a phase II open-label study. Neuro Oncol doi:10.1093/ neuonc/noq072

85. Vogelbaum MA, Peerboom G, Stevens G, Barnett G, Brewer C (2004) Phase II trial of the EGFR tyrosine kinase inhibitor erlotinib for single agent therapy of recurrent Glioblastoma Multiforme: Interim results [abstract]. J Clin Oncol 22:1558

86. Lassman AB, Rossi MR, Raizer JJ, Abrey LE, Lieberman FS, Grefe CN, Lamborn K, Pao W, Shih AH, Kuhn JG, Wilson R, Nowak NJ, Cowell JK, DeAngelis LM, Wen P, Gilbert MR, Chang S, Yung WA, Prados M, Holland EC (2005) Molecular study of malignant gliomas treated with epidermal growth factor receptor inhibitors: tissue analysis from North American Brain Tumor Consortium Trials 01-03 and 00-01. Clin Cancer Res 11:7841-7850 [published correction appears in Clin Cancer Res 2005;7812(7841):7322]

87. Clarke JL, Pao W, Wu N, Miller VA, Lassman AB (2010) High dose weekly erlotinib achieves therapeutic concentrations in CSF and is effective in leptomeningeal metastases from epidermal growth factor receptor mutant lung cancer. J Neurooncol doi:10.1007/s11060-010-0128-6

88. Hofer S, Frei K (2007) Gefitinib concentrations in human glioblastoma tissue. J Neurooncol 82:175-176

89. Kuhn J, Robins HI, Mehta M, Fine H, Cloughesy T, Wen PY, Chang S, DeAngelis LM, Lieberman F, Reardon D, Abrey LE, Lassman AB, Aldape K, Yung WK, Dancey J, Lamborn K, Prados M (2008) Tumor sequestration of lapatinib (NABTC 0401) [Abstract ET-05]. Neuro Oncol 10:783 
90. Haas-Kogan DA, Prados MD, Tihan T, Eberhard DA, Jelluma N, Arvold ND, Baumber R, Lamborn KR, Kapadia A, Malec M, Berger MS, Stokoe D (2005) Epidermal growth factor receptor, protein kinase B/Akt, and glioma response to erlotinib. J Natl Cancer Inst 97:880-887

91. Custodio A, Calles A, Perez-Segura P (2010) Response to erlotinib in recurrent glioblastoma multiforme showing coexpression of EGFRvIII and PTEN. Clin Transl Oncol 12:310-314

92. Brandes AA, Franceschi E, Tosoni A, Hegi ME, Stupp R (2008) Epidermal growth factor receptor inhibitors in neuro-oncology: hopes and disappointments. Clin Cancer Res 14:957-960

93. van den Bent MJ, Brandes AA, Rampling R, Kouwenhoven MC, Kros JM, Carpentier AF, Clement PM, Frenay M, Campone M, Baurain JF, Armand JP, Taphoorn MJ, Tosoni A, Kletzl H,
Klughammer B, Lacombe D, Gorlia T (2009) Randomized phase II trial of erlotinib versus temozolomide or carmustine in recurrent glioblastoma: EORTC brain tumor group study 26034. J Clin Oncol 27:1268-1274

94. Wick W, Weller M, van den Bent M, Stupp R (2010) Bevacizumab and recurrent malignant gliomas: a European perspective. J Clin Oncol 28:e188-189; author reply e190-182

95. Lai A, Filka E, McGibbon B, Nghiemphu PL, Graham C, Yong WH, Mischel P, Liau LM, Bergsneider M, Pope W, Selch M, Cloughesy T (2008) Phase II pilot study of bevacizumab in combination with temozolomide and regional radiation therapy for up-front treatment of patients with newly diagnosed glioblastoma multiforme: interim analysis of safety and tolerability. Int J Radiat Oncol Biol Phys 71:1372-1380 